\title{
Spatial Distribution Patterns of Appendicularians in the Drake Passage: Potential Indicators of Water Masses?
}

\author{
Marcin Kalarus ${ }^{1}$ and Anna Panasiuk ${ }^{2, *(D)}$ \\ 1 Department of Aquatic Ecology, Maritime Institute, Gdynia Maritime University, Smoluchowskiego 1/3, \\ 80-214 Gdańsk, Poland; Marcin.Kalarus@im.umg.edu.pl \\ 2 Department of Marine Plankton Research, Faculty of Oceanography and Geography, Institute of \\ Oceanography, University of Gdańsk, Av. Marszałka J. Piłsudskiego 46, 81-378 Gdynia, Poland \\ * Correspondence: anna.panasiuk@ug.edu.pl; Tel.: +485-8523-6844
}

Citation: Kalarus, M.; Panasiuk, A. Spatial Distribution Patterns of Appendicularians in the Drake Passage: Potential Indicators of Water Masses? Diversity 2021, 13, 286. https://doi.org/10.3390/d13070286

Academic Editor: Bert W. Hoeksema

Received: 28 May 2021

Accepted: 21 June 2021

Published: 23 June 2021

Publisher's Note: MDPI stays neutral with regard to jurisdictional claims in published maps and institutional affiliations.

Copyright: (c) 2021 by the authors. Licensee MDPI, Basel, Switzerland. This article is an open access article distributed under the terms and conditions of the Creative Commons Attribution (CC BY) license (https:/ / creativecommons.org/licenses/by/ $4.0 /)$.

\begin{abstract}
Appendicularians are one of the most common animals found within zooplankton assemblages. They play a very important role as filter feeders but are, unfortunately, inconsistently reported in the Antarctic literature. The present paper attempts to describe the zonal diversity of appendicularians and the main environmental factors influencing their communities in the Drake Passage. Samples were collected during Antarctic summer in 2009-2010. A total of eight species of larvaceans were identified. Fritillaria borealis was the species found in the highest numbers in almost the entire studied area, and was observed at all sampling stations. The distributions of other taxa were limited to specific hydrological zones and hydrological conditions. F. fraudax and Oikopleura gaussica were typical of the areas between the Polar Front and the Subantarctic Front zones, and their distributions were significantly correlated with temperature and salinity, likely making them good indicator species. The F. fusiformis distribution was strictly related to South American waters. In summary, temperature was the strongest environmental factor influencing the larvacean community structure in the Drake Passage, and we also found that testing environmental factors on larvaceans as a whole group did not give entirely reliable results.
\end{abstract}

Keywords: larvaceans; Drake Passage; latitudinal changes in assemblages; Fritillaria borealis; environmental conditions

\section{Introduction}

Appendicularians are one of the common animals within zooplankton assemblages and are widely distributed in all oceans [1]. These animals are filter feeders, consuming small particles, such as pico- and nanoplankton [2,3]. They build complex mucous houses that serve as filtering tools $[4,5]$. When the filters are clogged, these houses are rejected, and new houses can be secreted by the animals, even as often as every 2 to 4 hours; the houses can be used by other animals as food or as a fixation substrate [1]. Because of the high efficiency with which appendicularians ingest nanoplankton and picoplankton [6,7], they are able to create a path through which small cells cannot sink and, consequently, can be transported out of the euphotic zone [8]. As a result, when appendicularians are abundant, small phytoplankton cells can contribute much more to vertical carbon flow than when the same community is dominated by, for example, copepods [9]. Moreover, appendicularians have higher growth rates than copepods in response to an increase in food in their waters [10], and even short-term changes in their community structure may highly affect the particle flux in the local environment [8]. It should also be pointed out that, in some regions, appendicularians can be an important source of food for economically significant fishes, e.g., herring (Clupea harengus), South American pilchard (Sardinops sagax), or the Argentinean anchovy (Engraulis anchoita) [11].

Studies on the diversity, distribution, and abundance of Appendicularia in the Southern Ocean are very sparse and are limited to the genus or family levels, probably due 
to the fragility of appendicularians and the selectivity of the nets used [12,13]. A recent study conducted by some authors [14] noted a significant occurrence of appendicularians in the seasonal ice zone (SIZ) in the Southern Ocean. Other scientists [3] also surveyed Appendicularia diversity and abundance in the SIZ; they noted unusual high abundances of appendicularians and finally suggested that these animals are probably an integral part of the community structure of the zooplankton in the SIZ. Previously, Capitanio et al. [15] analyzed the variability in the characteristics that define the Oikopleura gaussica group in Antarctic waters. Furthermore, published data on appendicularians mainly concerned their role and importance in the Southern Ocean zooplankton community structure in general [13,14,16-19].

During the last few decades, the Antarctic ecosystem has been changing, mainly due to climatic fluctuations and the direct impacts of human activity $[20,21]$. These changes are visible not only in fluctuations of abiotic factors [22,23], but also at the functional level of the pelagic communities [24-28]. The responses of zooplankton to the warming Antarctic marine environment are very difficult to characterize due to the complex interactions between predators and prey $[29,30]$. Appendicularians are gelatinous zooplankton and, as mentioned above, they play an important role in global biogeochemical cycles because of their high grazing rates and significant role in the export of organic carbon from the ocean surface to the sea bottom [31,32]. However, it is still not clear how the abundance or frequency of occurrence of appendicularians will be affected by climate change [32-34].

The present paper contributes to the study of the species and zonal diversity, abundance, and biomass of appendicularians in the Drake Passage. We identified the main environmental factors influencing the distributions and abundances of selected species, and qualified the species that occurred in specific zones and preferred specific environmental conditions. Our results can be considered the first detailed study of these animals in this region, and may be an important contribution to a broader understanding of this rarely studied group of animals.

\section{Material and Methods}

\subsection{Study Area}

The Drake Passage is located between the southern tip of Tierra del Fuego (South America) and the Antarctic Peninsula, connecting the Atlantic Ocean with the Pacific Ocean. The width of the strait is over $800 \mathrm{~km}$, with an average depth up to $3400 \mathrm{~m}$, and a maximum depth of $4700 \mathrm{~m}$ [35]. In the investigated area, there is no latitudinal pressure gradient, creating a natural barrier that inhibits north-south geostrophic flow [36]. One of the effects of the zone's existence is the shift of the region of deepening and deep-water-forming to the north, which is also a key process shaping the global circulation system [37]. The volume of water flowing through the Drake Passage is estimated to be $134 \pm 11.2$ Sv [38]. The positions of the main current changes in this Antarctic region are very dynamic [39]. The Drake Passage is considered a very productive area (mainly due to the high krill biomass), but the primary production measurements obtained in the region are considered to be rather low, with average values ranging from 0.10 to $0.30 \mathrm{~g} \mathrm{C} \mathrm{m}^{-2} \mathrm{~d}^{-1}$ [40]. In the southern part of the Drake Passage, the primary production values range from 1.7 to $3.4 \mathrm{~g} \mathrm{C} \mathrm{m}^{-2} \mathrm{~d}^{-1}$ in December to $0.070-0.210 \mathrm{~g} \mathrm{C} \mathrm{m}^{-2} \mathrm{~d}^{-1}$ in March [40]. The chlorophyll concentration in the passage during Antarctic summer ranges from 0.1 to $1.0 \mathrm{mg} \mathrm{m}^{-3}$, and only locally reaches $2.87 \mathrm{mg} \mathrm{m}^{-3}$ (in the Subantarctic Front area and in the coastal waters of South America) [41,42].

\subsection{Sampling Collection and Laboratory Studies}

Samples were collected randomly during the Antarctic expedition of the Russian Academy of Sciences on the R/V "Akademik Ioffe" in January 2010 (Figure 1). Zooplankton were collected with a $100 \mu \mathrm{m}$ mesh size WP2-type net. The hauls were performed in layers from the depth ranges of 100-0 m, 200-100 m, and 300-200 m. At some research stations, it was not possible to close the net due to technical problems; therefore, at these stations, 
hauls were made from depth layers of 100-0 m, 200-0 m, and 300-0 m. Hydrological data, the temperature and salinity data of the surface water, as well as the concentrations of chlorophyll a, were provided by the Shirshov Institute of Oceanology of the Russian Academy of Sciences [41,42]. The investigated area was divided into seven characteristic zones [41,42] based on the phytoplankton and chlorophyll a concentration values (obtained during the same cruise). The following zones were identified (Figure 1): CAZ-Continental Antarctic Zone, SF-Southern Front, AZ-Antarctic Zone, PF-Polar Front, PFZ-Polar Frontal Zone, SAF-Subantarctic Front, SAZ-Subantarctic Zone.

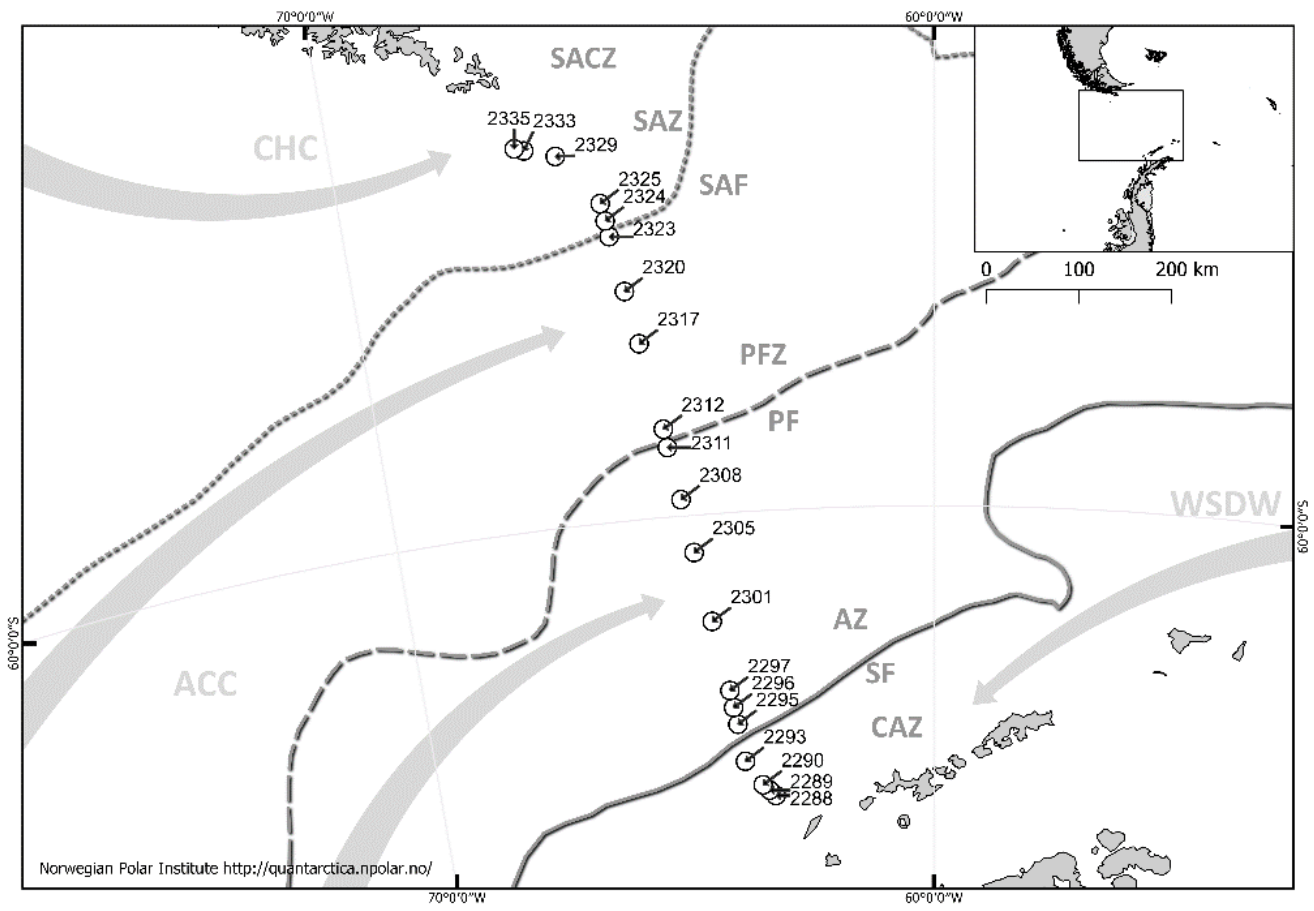

Figure 1. Geographical positions of the sampling stations, with the distinguished positions of the main hydrological zones in the Drake Passage in January 2010; ACC-Antarctic Circumpolar Current, CHC_Cape Horn Current, WSDW—Weddell Sea deep water.

In this study, collected zooplankton samples (51 in total; CAZ: 1, AZ: 16, SF: 3, PF: 3, PFZ: 12, SAF: 9, SAZ: 3, SACZ: 4) were analyzed to determine the qualitative and quantitative compositions of appendicularians that occurred in the Drake Passage. Taxonomic identifications were made to the lowest possible taxonomic level $[1,4,43,44]$. The obtained results were calculated as the number of individuals in $1000 \mathrm{~m}^{-3}$ of sea water. The biomasses of the four most common larvacean species (Table 1) were also estimated. For this purpose, morphometric measurements of all individuals identified in the samples were performed (if possible, due to the state of preservation). The length of the tail part (Lo) and length of the trunk $(\mathrm{Lt})$ were measured, adding up to a total of 16,786 measurements. In the cases of Fritillaria borealis and Oikopleura fusiformis, the regression patterns developed by Capitanio et al. [45], and Sato et al. [46] were used. The measured dry weight (DW) values were then converted to carbon $(C)$ weights using the ratio $C=0.45 \mathrm{DW}$ [47]. Due to the lack of any equation in the literature representing a regression of the length of the trunk to the mass of O. gaussica, the Deibel formula [48] was used, which has been tested for a morphologically similar species, O. vanhoeffeni $[43,49]$. Similarly, in the case of $F$. fraudax, the equation developed for $F$. borealis [45] was used. The obtained biomass values were then converted into micrograms of carbon in a given volume of filtered water $\left(\mu \mathrm{C} \mathrm{m}^{-3}\right)$ and in the integrated water column $(300-0 \mathrm{~m})$. 
Table 1. Trunk length-mass regression equations applied for the biomass calculations of investigated larvacean species; DW (dry weight), TL (trunk length), C (carbon content).

\begin{tabular}{ccc}
\hline Species & & Source \\
\hline Fritillaria borealis & $\log \mathrm{DW}(\mu \mathrm{g})=3.86 \log \mathrm{TL}(\mu \mathrm{m})-11.72$ & {$[45]$} \\
Fritillaria fraudax & $\log \mathrm{DW}(\mu \mathrm{g})=3.86 \log \mathrm{TL}(\mu \mathrm{m})-11.72$ & {$[45]$} \\
Oikopleura gaussica & $\mathrm{C}(\mu \mathrm{g})=4.59 \mathrm{TL}(\mathrm{mm})$ & {$[48]$} \\
Oikopleura fusiformis & $\log \mathrm{DW}(\mu \mathrm{g})=2.1 \log \mathrm{TL}(\mu \mathrm{m})-6.82$ & {$[46]$} \\
\hline
\end{tabular}

\subsection{Statistical Analyses}

Statistical data analyses were carried out in RStudio using R version 4.0.3 [50]. Multivariate statistical analyses were performed using the vegan package version $2.5-7$ in R [51]. Pairwise dissimilarity matrices were obtained among samples using Bray-Curtis dissimilarity (vegdist function). Nonmetric multidimensional scaling (NMDS, function metaMDS) was carried out with the dissimilarity matrices calculated for the appendicularian abundances, biomasses, and selected environmental factors. The NMDS plot was made using environmental vectors representing temperature, salinity, and chlorophyll (function envfit). Permutational multivariate analysis of variance (PERMANOVA) was performed to identify the most important environmental factors among temperature, salinity, and chlorophyll a for larvacean abundances and biomasses.

\section{Results}

\subsection{Hydrological Conditions}

The lowest temperature $\left(<1^{\circ} \mathrm{C}\right)$ obtained in this study was recorded close to the CAZ. The value of this measured parameter clearly increased towards the north $\left(\min .0 .43^{\circ} \mathrm{C}\right.$, max. $7.04^{\circ} \mathrm{C}$ ). The polar front zone was characterized by an increase in temperature to values above $2{ }^{\circ} \mathrm{C}$, and, further north, the temperature rose rapidly and reached approximately $6-7^{\circ} \mathrm{C}$ close to the SAF (Figure 2). The lowest salinity values (33.59) were observed within the AZ, and a minimum value was noted in the PF zone (Figure 2). The highest salinity (34.08) was observed in the SAF area, and, close to the American continent, the salinity decreased slightly again (Figure 2). The highest concentrations of chlorophyll a were recorded close to the front areas: $\mathrm{SF}, \mathrm{PF}$, and $\mathrm{SAF}$ (max. $0.42 \mathrm{mg} \mathrm{m}^{-3}$, $\min .0 .09 \mathrm{mg} \mathrm{m}^{-3}$ ) (Figure 2).

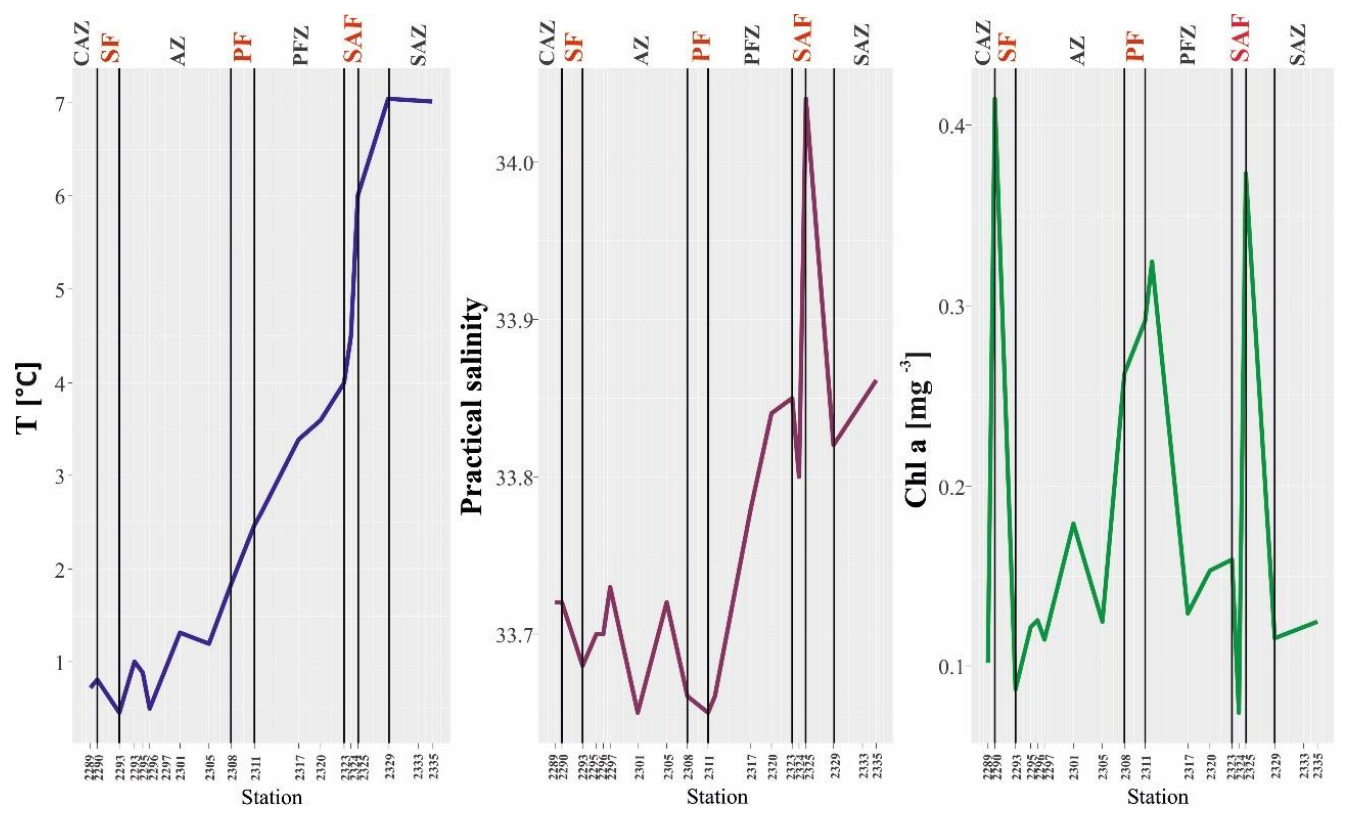

Figure 2. Variabilities in temperature $(\mathrm{T})\left({ }^{\circ} \mathrm{C}\right)$, salinity $(\mathrm{S})$, and chlorophyll a $\left(\mathrm{mg} \mathrm{m}^{-3}\right)$ in the surface water layer of the Drake Passage in January 2010. 


\subsection{Biogeographical Distribution of Appendicularia in the Drake Passage}

Eight species of Appendicularia were identified in the Drake Passage area: Fritillaria borealis, F. haplostoma, F. pellucida, F. fraudax, F. antarctica, Oikopleura fusiformis, O. parva, and O. gaussica. F. borealis was the most abundant species in almost the entire research area and was observed at all sampling stations, although, north of the Polar Front zone, the density of this species clearly decreased (Figures 3 and 4, Table 2). In the Antarctic Zone area, F. antarctica was also recorded; however, this species was present in a very small abundance (Figures 3 and 4, Table 2). Other investigated larvaceans were noted only at stations located north of the Polar Front, and this barrier clearly delimited their southern distribution, and, towards the north, the extinction and succession of these species were noticed. F. fraudax was typical of the PFZ area, O. gaussica was typical further north (SAF), and the area close to the American Continent (SAZ) was clearly an area of occurrence of O. fusiformis, while the Subantarctic Front was a clear southern limit of its occurrence (Figures 3 and 4, Table 2). Other observed species, F. pellucida, F. haplostoma. and O. parva, were rarely reported, and their densities were very low (Figures 3 and 4, Table 2).

Table 2. Abundances (means \pm SDs) (ind. $10^{3} \mathrm{~m}^{-3}$ ) of appendicularians in the $300-0 \mathrm{~m}$ water layer of the Drake Passage in January 2010.

\begin{tabular}{cccccccccc}
\hline \multirow{2}{*}{$\begin{array}{c}\text { Species } \\
\text { Passage }\end{array}$} & CAZ & SF & AZ & PF & PFZ & SAF & SAZ & SACZ \\
\cline { 2 - 9 } & $3177 \pm 4514$ & 5684 & 8887 & $3418 \pm 5242$ & 1989 & $1392 \pm 1153$ & $866 \pm 1108$ & 433 & $2125 \pm 861$ \\
\hline Fritillaria borealis & $1 \pm 5$ & 0 & 0 & 0 & 20 & 0 & 0 & 0 \\
\hline $\begin{array}{c}\text { Fritillaria } \\
\text { haplostoma }\end{array}$ & $2 \pm 7$ & 0 & 0 & $0 \pm 2$ & 0 & 0 & 0 & 0 & $20 \pm 10$ \\
\hline $\begin{array}{c}\text { Fritillaria pellucida } \\
\text { Fritillaria }\end{array}$ & $18 \pm 62$ & 81 & 0 & $45 \pm 111$ & 0 & 0 & 0 & 0 & 0 \\
\hline $\begin{array}{c}\text { antarctica } \\
\text { Fritillaria fraudax }\end{array}$ & $405 \pm 880$ & 0 & 0 & 0 & 81 & $1490 \pm 1561$ & $623 \pm 551$ & 68 & $61 \pm 86$ \\
\hline $\begin{array}{c}\text { Oikopleura } \\
\text { fusiformis }\end{array}$ & $602 \pm 1510$ & 0 & 0 & 0 & 0 & $7 \pm 14$ & $821 \pm 1180$ & 284 & $4635 \pm 1656$ \\
\hline $\begin{array}{c}\text { Oikopleura parva } \\
\text { Oikopleura sp }\end{array}$ & $1 \pm 4$ & 0 & 0 & $2 \pm 0$ & 0 & $3 \pm 7$ & 0 & 0 \\
\hline $\begin{array}{c}\text { Oikopleura } \\
\text { gaussica }\end{array}$ & $321 \pm 484$ & 0 & 11 & 0 & 508 & $641 \pm 652$ & $1011 \pm 353$ & 135 & $61 \pm 48$ \\
\hline Appendicularia & $4779 \pm 4310$ & 5765 & 8911 & $3474 \pm 5278$ & 2274 & $3223 \pm 2523$ & $3095 \pm 536$ & 907 & $6882 \pm 641$ \\
\hline
\end{tabular}

The biomass of Fritillaria borealis grew towards the northern region of the investigated transect (in contrast to the abundance results), and the highest values were observed north of the Polar Front zone (Figure 5). The two sampling stations at which the highest biomasses of this species were recorded were in the SAZ (station 2333; 334.01 $10^{3} \mu \mathrm{g} \mathrm{C} \mathrm{m}^{-3}$ ) and within the SAF (station 2323; $259.6010^{3} \mathrm{\mu g} \mathrm{C} \mathrm{m}^{-3}$ ). Another Fritillaria species, F. fraudax, reached its highest biomass in the PFZ at $1.418 .0510^{3} \mu \mathrm{g} \mathrm{C} \mathrm{m}{ }^{-3}$ (Figure 5). Its biomass then decreased towards the north (Figure 5). The highest biomass of Oikopleura gaussica was observed in the SAF zone at $12029.5910^{3} \mathrm{\mu g} \mathrm{C} \mathrm{m}^{-3}$ (Figure 5). O. fusiformis was the species with the highest biomass among the identified taxa (Table 3). The highest values were observed in the northern part of the transect, such as the value of $2558.2610^{3} \mu \mathrm{g} \mathrm{C} \mathrm{m}^{-3}$ recorded in the SAZ (station 2335), and smaller peaks were also noticeable in the SAF and PFZ (Figure 5). 


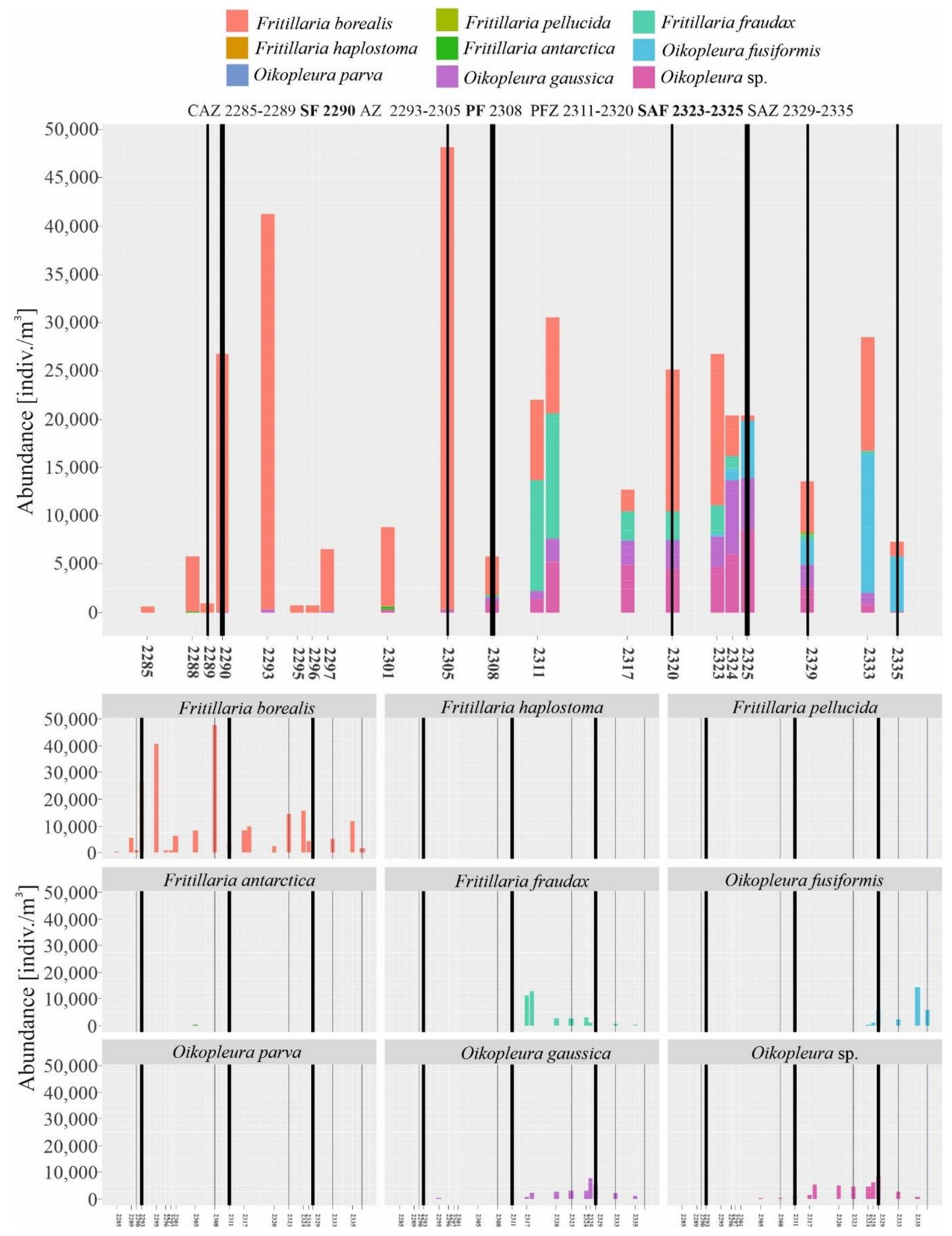

Figure 3. Diversity and abundance of Appendicularia across the investigated stations in the Drake Passage (with remarks on the biogeographical zones) in January 2010. 


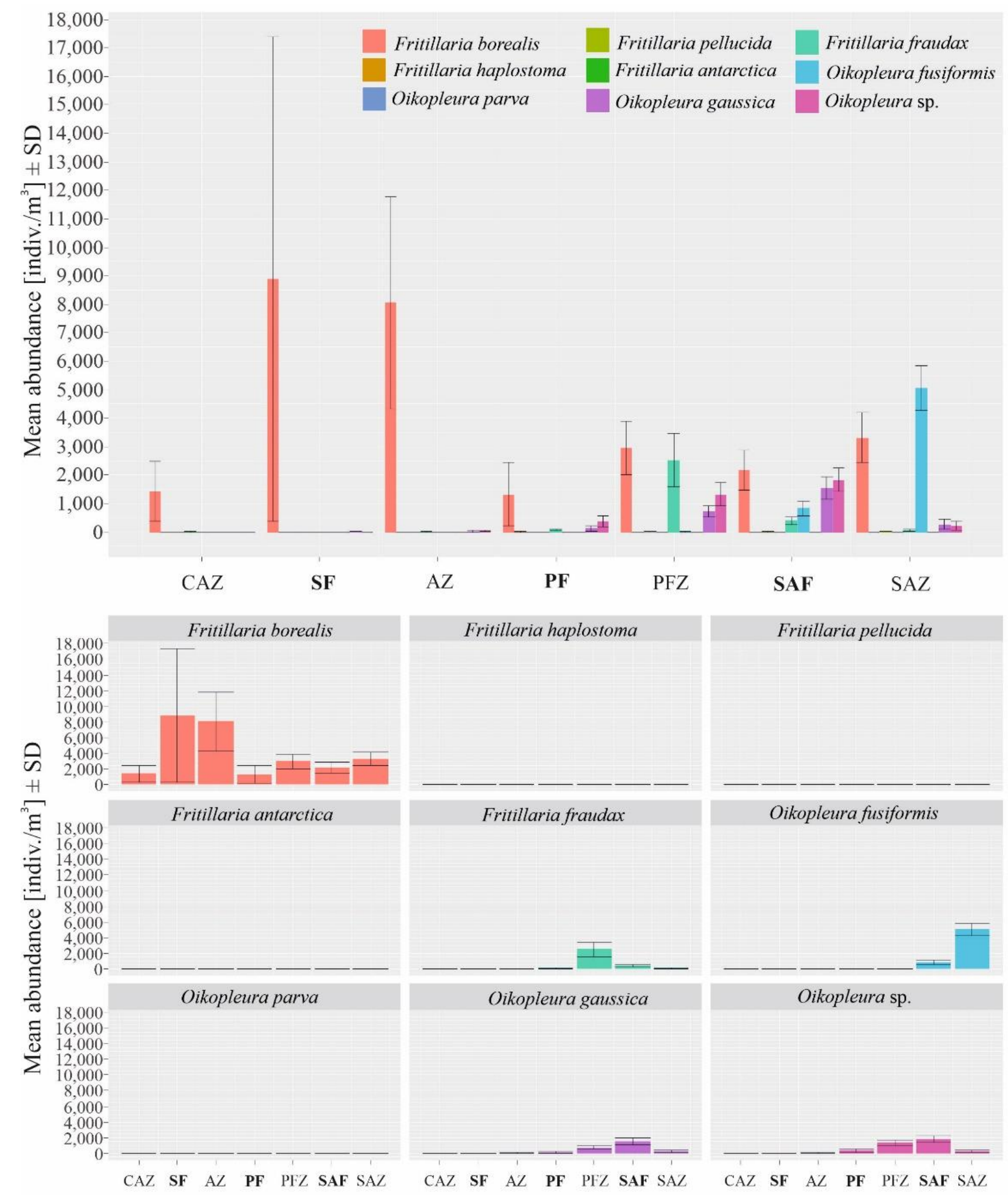

Figure 4. Diversity and abundance of Appendicularia across the specific biogeographical zones in the Drake Passage in January 2010. 

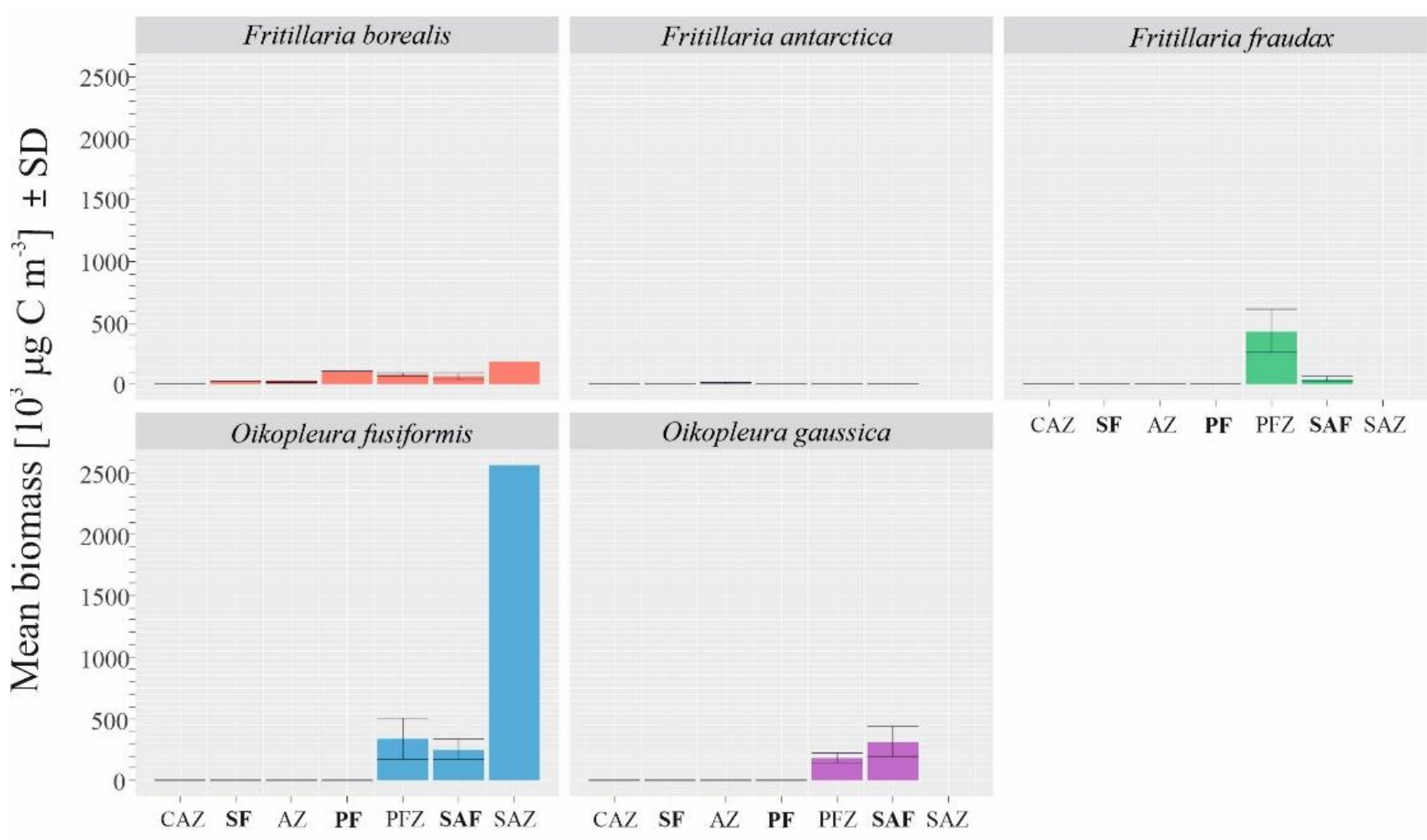

Figure 5. Mean biomasses of the most abundant Appendicularia species across the specific biogeographical zones in the Drake Passage in January 2010.

Table 3. Mean biomasses $\left(10^{3} \mu \mathrm{g} \mathrm{C} \mathrm{m}^{-3}\right)$ of appendicularians in the $300-0 \mathrm{~m}$ water layer in the Drake Passage in January 2010.

\begin{tabular}{cc}
\hline Species & Biomass $\left.\mathbf{( 1 0}^{\mathbf{3}} \boldsymbol{\mu} \mathbf{g ~ C ~} \mathbf{~}^{-\mathbf{3}}\right)$ \\
\hline Fritillaria borealis & $73.79 \pm 90.35$ \\
\hline Fritillaria fraudax & $96.85 \pm 308.26$ \\
\hline Oikopleura gaussica & $101.69 \pm 232.87$ \\
\hline Oikopleura fusiformis & $321.28 \pm 677.54$ \\
\hline
\end{tabular}

\subsection{Environmental Factors Influencing the Zonal Distribution of Appendicularia}

The influences of environmental factors on the abundance and biomass of Appendicularia in the Drake Passage were investigated based on the temperature (T), salinity (S), and chlorophyll a (Chl a) concentration in the surface water layer. The results showed that, among the tested factors, the surface water temperature (T) and salinity (S) were statistically significantly $(p<0.05)$ correlated with the abundances and biomasses of appendicularians (Table 4). Temperature was a very important factor influencing the distributions of Fritillaria antarctica, F. fraudax, Oikopleura fusiformis, and O. gaussica (Table 4). The chlorophyll a concentrations were statistically significant only in the case of O. gaussica (Table 4). Based on the obtained results, we were able to distinguish three types of species among the investigated larvaceans: F. borealis, a cold-water species that occurred in all zones of the passage and for which environmental factors were not statistically significant; $F$. fraudax and O. gaussica, cold-water species that occurred between the PF and the SAF, were limited by specific water masses and environmental conditions, and for which $\mathrm{T}, \mathrm{S}$, and $\mathrm{Chl}$ a were statistically significant; and O. fusiformis, a warm-water species that occurred in the SAZ, was limited by specific water masses and environmental conditions, and for which $\mathrm{T}$ and $\mathrm{S}$ were statistically significant (Table 4, Figure 6). 


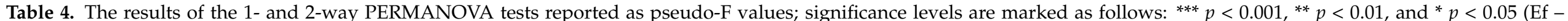

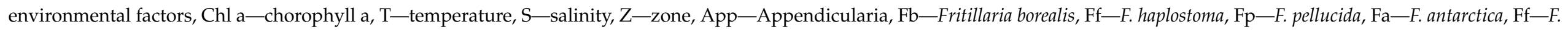
fraudax, Of-Oikopleura fusiformis, Op-O. parva, Og-O. gaussica, and O-Oikopleura sp.).

\begin{tabular}{|c|c|c|c|c|c|c|c|c|c|c|c|c|c|c|c|}
\hline \multirow[b]{2}{*}{ Ef } & \multirow[b]{2}{*}{$\begin{array}{l}\text { Df } \\
R\end{array}$} & \multicolumn{10}{|c|}{ Abundance (ind. $10^{-3} \mathrm{~m}^{3}$ ) } & \multicolumn{4}{|c|}{ Biomass $\left(10^{3} \mu \mathrm{g} \mathrm{C} \mathrm{m}^{-3}\right)$} \\
\hline & & App & $F b$ & $F h$ & $F p$ & $F a$ & $F f$ & Of & $O p$ & $O g$ & $O$ & $F b$ & $F a$ & Of & $O g$ \\
\hline Chl a & $\begin{array}{c}1 \\
45\end{array}$ & 0.607 & 1.2827 & 0.4724 & 0.5911 & 0.0166 & 1.1251 & 1.3576 & 0.4371 & $3.5536^{*}$ & 0.2951 & 2.3743 & 0.0193 & 2.4803 & 1.7626 \\
\hline $\mathbf{T}$ & $\begin{array}{l}17 \\
29\end{array}$ & $2.0373^{* * *}$ & 1.1479 & 0.7985 & 2.0905 & $10.319^{* * *}$ & $8.5419 * * *$ & $6.8241^{* * *}$ & 0.7509 & $2.5872 * * *$ & $3.9824^{* * *}$ & $-1.7976 \times 10^{17}$ & $9.156 \times 10^{17 * * *}$ & $9.6813 \times 10^{16}$ & $36.071^{* * *}$ \\
\hline 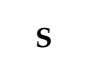 & $\begin{array}{c}1 \\
45\end{array}$ & $5.6876^{* * *}$ & 0.6531 & 0.9379 & 0.0561 & 2.0514 & 2.7163 & $30.529 * * *$ & 0.1458 & $6.4235^{* * *}$ & $8.2766^{* * *}$ & $6.1528^{* *}$ & 2.4086 & $39.397^{* * *}$ & $5.5897^{* *}$ \\
\hline $\begin{array}{c}T^{*} \\
\text { Chl_a }\end{array}$ & $\begin{array}{l}17 \\
29\end{array}$ & $2.0373^{* * *}$ & 1.1479 & 0.7985 & 2.0905 & $10.319^{* * *}$ & $8.5419^{* * *}$ & $6.8241^{* * *}$ & 0.7509 & $2.5872 * * *$ & $3.9824^{* * *}$ & $-1.7976 \times 10^{17}$ & $9.156 \times 10^{17 * * *}$ & $9.6813 \times 10^{16}$ & $36.071^{* * *}$ \\
\hline$T^{*} \mathrm{~S}$ & $\begin{array}{l}17 \\
29\end{array}$ & $2.0373^{* * *}$ & 1.1479 & 0.7985 & 2.0905 & $10.319 * * *$ & $8.5419^{* * *}$ & $6.8241^{* * *}$ & 0.7509 & $2.5872^{* * *}$ & $3.9824^{* * *}$ & $-1.7976 \times 10^{17}$ & $9.156 \times 10^{17 * * *}$ & $9.6813 \times 10^{16}$ & $36.071^{* * *}$ \\
\hline $\mathrm{z}$ & $\begin{array}{c}1 \\
45\end{array}$ & $9.9469^{* * *}$ & 1.8119 & 0.0213 & 2.6486 & 1.0618 & $26.043^{* * *}$ & $27.878^{* * *}$ & 0.0906 & $16.678^{* * *}$ & $30.08^{* * *}$ & $24.818^{* * *}$ & 1.2421 & $32.616^{* * *}$ & $25.034^{* * *}$ \\
\hline
\end{tabular}




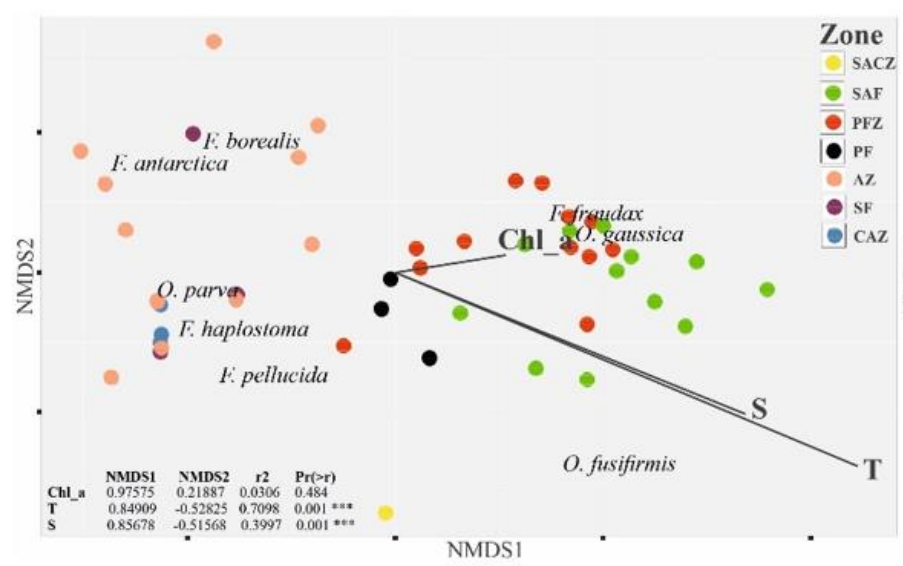

(A) $x$

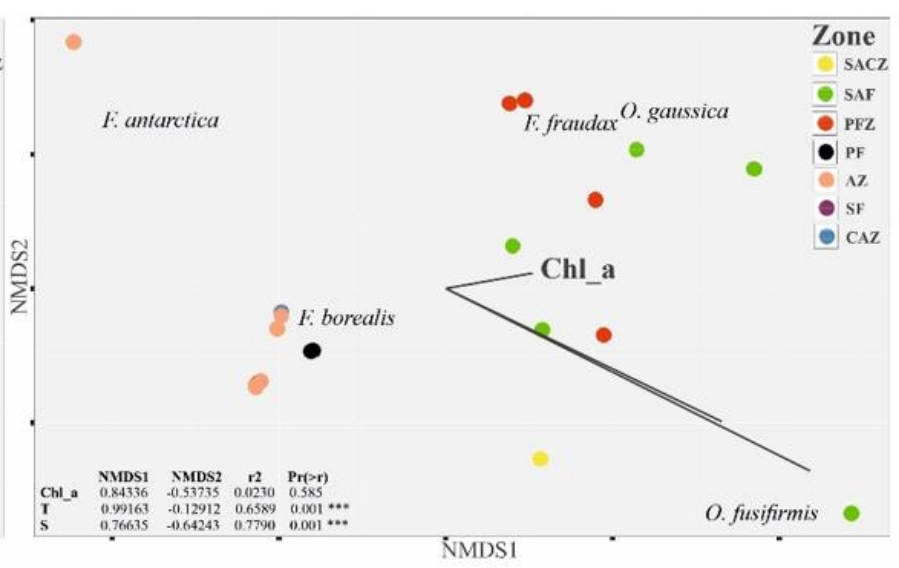

(B)

Figure 6. Ordination of the sampling plots in an NMDS space based on the Bray-Curtis dissimilarities of Appendicularia species abundances (A) and biomasses (B) measured in the Drake Passage in January 2010. The points represent the placement of plots, and the name of species represents the placement of that species within the multidimensional space. The landscape variables explaining the differences in abundance and biomass between the plots are represented as vectors and were fitted using the function envfit (R-package vegan); Signif. codes: ‘***` 0.001 .

\section{Discussion}

In January 2010, during the 2009-2010 expedition to the Drake Passage area, we found eight species of larvaceans. During previous research conducted in the southern part of the Bransfield Strait (Antarctic Peninsula region), some authors [52,53] only noted the presence of unidentified appendicularians. On the western side of the Drake Passage, Takahashi et al. [54] reported the presence of species from the genus Oikopleura, while Capitanio et al. [15] identified Fritillaria borealis, O. fusiformis, and O. gaussica in the waters of the Bellingshausen Sea and around South Georgia. The abundances of appendicularians observed in the Drake Passage during our study were comparable to the results presented by Jażdżewski et al. [52], but the abundances obtained herein were significantly higher (even $100 \times$ higher) than those reported by Witek et al. [53]. It should be pointed out that the zooplankton samples analyzed in the studies of Jażdżewski et al. [52] were collected in February and March, and those analyzed by Witek et al. [53] were obtained in December and January, while, in our study conducted in 2010, samples were collected at the beginning of January. Presumably, in the case of the results of Witek et al. [53], the Appendicularia population had not yet developed, while, during our studies, most of the recorded individuals were relatively small and were supposedly at early stages of ontogenesis. Jażdżewski et al. [52] explained that large abundances of rather small appendicularians are typical for the water masses around the Bellingshausen Sea. During our study, samples were taken from a similar region—south of the PF zone-and we noted a distinct dominance of relatively small $F$. borealis individuals. In comparison to the northern parts of the Drake Passage (along Argentina's eastern coast), the abundance and biomass observations obtained in this study were approximately 1000 times lower than the values reported by, e.g., Capitanio et al. [45]. Most likely, the very high abundances observed by Capitanio et al. [45] can be explained by the high abundances of $O$. dioica reported in their study; this species was not found in the Drake Passage during our study.

\subsection{Biogeographical Distribution of Appendicularia in the Drake Passage and the Main Zones of Occurrence}

During our study, Fritillaria borealis was observed within all investigated areas; however, the highest abundances were noted in the AZ area, while, in contrast, the biomass of this species grew to the north. In our opinion, this result is mainly due to the reproductive 
process beginning earlier in the northern regions than in the southern regions and, hence, larger specimens were recorded in the northern regions, resulting in higher biomass measurements in these areas. In the Antarctic Zone area, many individuals were recorded, but these individuals were at an early stage of development. In the Southern Ocean region, F. borealis is a very common species and was previously noted by Aguirre et al. [19]. This species occurred in all zones of the Drake Passage, from the Continental Antarctic Zone to the South American Zone.

Based on our results, we were able to identify species with very narrow ranges of occurrence. During our study, Fritillaria fraudax was noted only in the area between the Polar Front and the Subantarctic Front zones, as was Oikopleura gaussica. However, F. fraudax appeared to be a slightly "cooler" species compared to O. gaussica because the former was recorded at its highest density and biomass slightly to the north of the Polar Front zone, while the latter species was abundant near the Subantarctic Front zone. In the case of F. fraudax, it was very difficult to compare our results with previously collected data because this species has not been registered in this region in the past. According to Esnal $[1,4]$, this larvacean is a thermophilic and cosmopolite species; however, Aravena and Palma [2], based on results obtained from the northern waters of Chile, suggested that $F$. fraudax is a nearshore species with a preference for neritic waters, although they pointed out that this species can also occur in oceanic waters. Through analysis of our results, we can say that the presence of this species is rather limited to specific types of water masses (with specific thermal conditions). O. gaussica is the name used for a group of species: O. gaussica, O. valdiviae, O. drygalski, and O. weddelli [54]. This species was, for example, recorded by Lindsay and Williams [55] in the southwest Indian Ocean sector of East Antarctica, and the highest abundances obtained in their study were found north of the Antarctic Circumpolar Current. During our study, the distribution of this species was limited by the Polar Front and Subantarctic Front zones, and the area between these zones was the main area of occurrence of this larvacean.

\subsection{Environmental Factors Influencing the Zonal Distribution of Appendicullaria}

Primary production is mainly driven by temperature and nutrient availability, and these factors also impact appendicularian population dynamics [34,56]. During our study, the main statistically significant environmental factor responsible for variabilities in Appendicularia was the water temperature, which was consistent with the observations of Gorsky et al. [57], who recognized that temperature was the factor that most determined the structure of these animals. Consistent with previous observations by other authors e.g. [34,56], high abundances of Appendicularia should be observed in areas with very high phytoplankton biomasses and chlorophyll a contents; however, during our study, it was clear that the stations with the highest chlorophyll a concentrations did not correspond with the highest larvacean abundances or biomasses. The frontal zones, the SF, PF, and SAF, in the Drake Passage were the areas with the highest chlorophyll a concentrations, and very high densities of other zooplanktonic organisms have also often been observed in these regions by other authors e.g., [58-61]. One explanation for this phenomenon was provided by López Urrutia et al. [62], who recorded that predation by copepods on appendicularian eggs and juveniles can significantly limit their population growth rates. Hopcroft et al. [10] pointed out that both the potential size spectrum of food and its efficiency of utilization are influenced by the body size of appendicularians, and small species can obtain even very small particles so they may avoid problems with resource limitations. Importantly, we recorded that, in the case of appendicularians, all tested environmental factors were significant when all larvaceans were analyzed as a group. The results of the analyses that were performed separately for each species showed differences in the "sensitivity" of individual species to the studied factor.

According to the opinion of Atkinson et al. [12], "appendicularians are inconsistently reported in the Antarctic literature", and this is probably the result of net selectivity (usually krill or salps are the main subject of research), but the delicate body structure of these 
animals also makes them extremely difficult to study. The Southern Ocean and Antarctica are warming [63], and the physicochemical characteristics of their waters make this region particularly susceptible to ocean acidification [64]. According to Troedsson et al. [34], a lower $\mathrm{pH}$ would favor appendicularian fitness, and lead to an increase in their ecological importance. However, the increased ecological importance of these animals, along with progressive climate changes, would be in line with the general trend of the increasing importance of jellyfish organisms (e.g., tunicates and cnidarians) in all marine environments [32], including polar regions [65-69].

\section{Conclusions}

1. Fritillaria borealis was a widespread species in the Drake Passage; high abundances were noted across all investigated areas, and we did not find any significant correlation between its abundance and the tested environmental factors.

2. F. fraudax and Oikopleura gaussica were typical species in the area between the Polar Front and Subantarctic Front zones, and their distributions and abundances were significantly correlated with temperature and salinity.

3. F. fusiformis is a warm water species and its distribution was strictly related to South American waters.

4. Temperature was the strongest environmental factor (not the concentration of chlorophyll a) which influences the larvaceans community structure in the Drake Passage.

5. Testing environmental factors on larvaceans as a whole group cannot provide entirely reliable results; by taking into account only this approach during the research conducted in this study, all environmental factors were found to be significant.

Author Contributions: M.K. managed the laboratory analysis, dataset preparation, and the analysis and interpretation of the results, and was responsible for the management and preparation of the manuscript. A.P. was responsible for the sample collection and organizing the dataset, data analysis and interpretation, and management and preparation of the manuscript. Both authors have read and agreed to the published version of the manuscript.

Funding: This work was supported by research grant No. N306 445638 (2010-2012) awarded to the Institute of Oceanography (University of Gdańsk) by the Ministry of Science and Higher Education (Poland).

Institutional Review Board Statement: This article does not contain any studies with human participants or animals performed by any of the authors. This is an observational study and no ethical approval is required.

Informed Consent Statement: Informed consent was obtained from all subjects involved in the study.

Data Availability Statement: The datasets analyzed during the current study are available from the corresponding author on reasonable request.

Acknowledgments: We wish to thank the Shirshov Institute of Oceanology of the Russian Academy of Sciences and the Polish Academy of Sciences for the opportunity to collect zooplankton samples, and the crew of R/V Akademik Ioffe. We would like to thank Luiza Bielecka and Maciej Wołowicz for their assistance in the collection of samples. In particular, we would like to thank Maria Iwona Żmijewska for her invaluable help and supervision of our research.

Conflicts of Interest: The authors declare that they have no conflict of interest.

\section{References}

1. Esnal, G. Apendicularia. In Atlas del Zooplancton del Atlántico Sudoccidental y Métodosde Trabajo Con el Zooplancton Marino; Boltovskoy, D., Ed.; Publicación Especial; Instituto Nacional de Investigacióny Desarrollo Pesquero: Mar del Plata, Argentina, 1981; pp. 809-820.

2. Aravena, G.; Palma, S. Taxonomic identification of appendicularians collected in the epipelagic waters off northern Chile (Tunicata, Appendicularia). Rev. Chil. Hist. Nat. 2002, 75, 307-325. [CrossRef]

3. Tsujimoto, M.; Takahashi, K.T.; Hirawake, T.; Mitsuo, F. Unusual abundance of appendicularians in the seasonal ice zone (140 $\left.{ }^{\circ} \mathrm{E}\right)$ of the Southern Ocean. Polar Biosci. 2006, 19, 133-141. 
4. Esnal, G. Appendicularia. In South Atlantic Zooplankton; Boltovskoy, D., Ed.; Backhuys Publication: Leiden, The Netherlands, 1999; pp. 1375-1399.

5. Sato, R.; Tanaka, Y.; Ishimaru, T. House Production by Oikopleura dioica (Tunicata, Appendicularia) Under Laboratory Conditions. J. Plankton Res. 2001, 23, 415-423. [CrossRef]

6. Deibel, D.; Lee, S.H. Retention efficiency of sub-micrometer particles by the pharyngeal filter of the pelagic tunicate Oikopleura vanhoeffeni. Mar. Ecol. Prog. Ser. 1992, 81, 25-30. [CrossRef]

7. Acuña, J.L.; Deibel, D.; Morris, C.C. Particle capture mechanism of the pelagic tunicate Oikopleura vanhoeffeni. Limnol. Oceanogr. 1996, 41, 1800-1814. [CrossRef]

8. Vargas, C.A.; Tönnesson, K.; Sell, A.; Maar, M.; Friis Møller, E.; Zervoudaki, T.; Giannakourou, A.; Christou, E.; Satapoomin, S.; Kjerulf Petersen, J.; et al. Importance of copepods versus appendicularians in vertical carbon fluxes in a Swedish fjord. Mar. Ecol. Prog. Ser. 2002, 241, 125-138. [CrossRef]

9. Hansen, J.L.S.; Kiørboe, T.; Alldredge, A.L. Marine snow derived from abandoned larvacean houses: Sinking rates, particle content and mechanisms of aggregate formation. Mar. Ecol. Prog. Ser. 1996, 141, 205-215. [CrossRef]

10. Hopcroft, R.R.; Roff, J.C.; Bauman, H.A. Zooplankton growth rates: The larvaceans Appendicularia, Fritillaria and Oikopleura in tropical waters. J. Plankton Res. 1998, 20, 539-555. [CrossRef]

11. Capitanio, F.; Pajaro, M.; Esnal, G. Appendicularians (Chordata, Tunicata) in the diet of anchovy (Engraulis anchoita) in the Argentine sea. Sci. Mar. 1997, 61, 9-15.

12. Atkinson, A.; Ward, P.; Hunt, B.P.V.; Pakhomov, E.A.; Hosie, G.W. An Overview of Southern Ocean zooplankton data: Abundance, biomass, feeding and functional relationship. CCAMLR Sci. 2012, 19, 171-218.

13. Spinelli, M.L.; Franzosi, C.; Olguin Salinas, H.; Capitanio, F.L.; Alder, V.A. Appendicularians and copepods from Scotia Bay (Laurie island, South Orkney, Antarctica): Fluctuations in community structure and diversity in two contrasting, consecutive summers. Pol. Biol. 2018, 41, 663-678. [CrossRef]

14. Hunt, B.P.V.; Hosie, G.W. Zonal structure of zooplankton communities in the Southern Ocean South of Australia: Results from a $2150 \mathrm{~km}$ continuous plankton recorder transect. Deep Sea Res. I 2005, 52, 1241-1271. [CrossRef]

15. Capitanio, F.L.; Daponte, M.C.; Esnal, G.B. The classification of Antarctic appendicularians: The Oikopleura gaussica group. Ant. Sci. 2003, 15, 476-482. [CrossRef]

16. Chiba, S.; Ishimaru, T.; Hosie, G.W.; Fukuchi, M. Spatio-temporal variability of zooplankton community structure off east Antarctica (90 to $160^{\circ}$ E). Mar. Ecol. Prog. Ser. 2001, 216, 95-108. [CrossRef]

17. Ward, P.; Shreeve, R.; Whitehouse, M.; Korb, B.; Atkinson, A.; Meredith, M.; Pond, D.; Watkins, J.; Goss, C.; Cunningham, N. Phyto- and zooplankton community structure and production around South Georgia (Southern Ocean) during summer 2001/02. Deep Sea Res. I 2005, 52, 421-441. [CrossRef]

18. McLeod, D.J.; Hosie, G.W.; Kitchener, J.A.; Takahashi, K.T.; Hunt, B.P.V. Zooplankton atlas of the Southern Ocean: The SCAR SO-CPR survey (1991-2008). Polar Sci. 2010, 4, 353-385. [CrossRef]

19. Aguirre, G.E.; Capitanio, F.L.; Lovrich, G.A.; Esnal, G.B. Seasonal variability of metazooplankton in coastal sub-Antarctic waters (Beagle Channel). Mar. Biol. Res. 2012, 8, 341-353. [CrossRef]

20. Turner, J.; Barrand, N.E.; Bracegirdle, T.J.; Convey, P.; Hodgson, D.; Jarvis, M.; Jenkins, A.; Marshall, G.; Meredith, M.P.; Roscoe, H.; et al. Antarctic climate change and the environment: An update. Polar Rec. 2014, 50, 237-259. [CrossRef]

21. Convey, P.; Peck, L.S. Antarctic environmental change and biological responses. Sci. Adv. 2019, 5, eaaz0888. [CrossRef]

22. Lee, J.R.; Raymond, B.; Bracegirdle, T.J.; Chadès, I.; Fuller, R.A.; Shaw, J.D.; Terauds, A. Climate change drives expansion of Antarctic ice-free habitat. Nature 2017, 547, 49-54. [CrossRef]

23. Kobusińska, M.E.; Lewandowski, K.K.; Panasiuk, A.; Łęczyński, L.; Urbaniak, M.; Ossowski, T.; Niemirycz, E. Precursors of polychlorinated dibenzo-p-dioxins and dibenzofurans in Arctic and Antarctic marine sediments: Environmental concern in the face of climate change. Chemosphere 2020, 260, 127605. [CrossRef] [PubMed]

24. Atkinson, A.; Siegel, V.; Pakhomov, E.; Rothery, P. Long-term decline in krill stock and increase in salps within the Southern Ocean. Nature 2004, 432, 100-103. [CrossRef]

25. Peck, L.S. Antarctic marine biodiversity: Adaptations environments and responses to change. Oceanogr. Mar. Biol. 2018, 56, 105-236.

26. Henley, S.; Schofield, O.; Hendry, K.; Schloss, I.; Steinberg, D.; Moffat, C.; Peck, L.; Costa, D.; Bakker, D.; Hughes, C.; et al. Variability and change in the west Antarctic Peninsula marine system: Research priorities and opportunities. Prog. Oceanogr. 2019, 173, 208-237. [CrossRef]

27. Potocka, M.; Kidawa, A.; Panasiuk, A.; Bielecka, L.; Wawrzynek-Borejko, J.; Patuła, W.; Wójcik, K.A.; Plenzler, J.; Janecki, T.; Bialik, R.J. The effect of glacier recession on benthic and pelagic communities: Case study in Herve cove, Antarctica. J. Mar. Sci. Eng. 2019, 7, jmse7090285. [CrossRef]

28. Panasiuk, A.; Wawrzynek-Borejko, J.; Musiał, A.; Korczak-Abshire, M. Pygoscelis penguin diets on King George Island, South Shetland Islands, with a special focus on the krill Euphausia Superba. Ant. Sci. 2020, 32, 21-28. [CrossRef]

29. Wirtz, K.W. Who is eating whom? Morphology and feeding type determine the size relation between planktonic predators and their ideal prey. Mar. Ecol. Prog. Ser. 2012, 445, 1-12. [CrossRef]

30. Garcia, M.D.; Dutto, M.S.; Chazarreta, C.J.; Berasategui, A.A.; Schloss, I.R.; Hoffmeyer, M.S. Micro- and mesozooplankton successions in an Antarctic coastal environment during a warm year. PLoS ONE 2020, 15, e0232614. [CrossRef] [PubMed] 
31. Lebrato, M.; de Jesus Mendes, P.; Steinberg, D.K.; Cartes, J.E.; Jones, B.M.; Birsa, L.M.; Benavides, R.; Oschlies, A. Jelly biomass sinking speed reveals a fast carbon export mechanism. Limnol. Oceanogr. 2013, 58, 1113-1122. [CrossRef]

32. Winder, M.; Bouquet, J.-M.; Bermúdez, J.R.; Berger, S.A.; Hansen, T.; Brandes, J.; Sazhin, A.F.; Nejstgaard, J.C.; Båmstedt, U.; Jakobsen, H.H.; et al. Increased appendicularian zooplankton alter carbon cycling under warmer more acidified ocean conditions. Limnol. Oceanogr. 2017, 62, 1541-1551. [CrossRef]

33. Richardson, A.J.; Bakun, A.; Hays, G.C.; Gibbons, M.J. The jellyfish joyride: Causes, consequences and management responses to a more gelatinous future. Trends Ecol. Evol. 2009, 24, 312-322. [CrossRef] [PubMed]

34. Troedsson, C.; Bouquet, J.-M.; Lobon, C.M.; Novac, A.; Nejstgaard, J.C.; Dupont, S.; Bosak, S.; Jakobsen, H.H.; Romanova, N.; Pankoke, L.M.; et al. Effects of ocean acidification, temperature and nutrient regimes on the appendicularian Oikopleura dioica: A mesocosm study. Mar. Biol. 2012, 160, 2175-2187. [CrossRef]

35. Deacon, G.E.R. A general account of the hydrology of the South Atlantic Ocean. Discov. Rep. 1933, VII, $177-238$.

36. Toggweiler, J.R.; Samuels, B. Effect of Drake Passage on the global thermohaline circulation. Deep Sea Res. I 1995, 42, 477-500. [CrossRef]

37. Cox, M.D. An idealized model of the world ocean. Part I: The global-scale water masses. J. Phys. Oceanogr. 1989, 19, 1730-1752. [CrossRef]

38. Whitworth, T., III.; Peterson, R.G. Volume transport of the Antarctic Circumpolar Current from bottom pressure measurements. J. Phys. Oceanogr. 1985, 15, 810-816. [CrossRef]

39. Cunningham, S.A.; Alderson, S.G.; King, B.A. Transport and variability of the Antarctic Current in Drake Passage. J. Geophys. Res. 2003, 108, 80-84. [CrossRef]

40. Holm-Hansen, O.; Mitchell, B.G. Spatial and temporal distribution of phytoplankton and primary production in the western Bransficld Strait region. Deep Sea Res. 1991, 38, 961-9811. [CrossRef]

41. Demidov, A.B.; Gagarin, V.I.; Grigoriev, A.V. Seasonal Variability of the Surface Chlorophyll a in the Drake Passage. Oceanology 2010, 50, 327-341. [CrossRef]

42. Demidov, A.B.; Mosharov, S.A.; Gagarin, I. Phytoplankton Production Characteristics in the Southern Atlantic and the Atlantic Sector of the Southern Ocean in the Astral Summer of 2009-2010. Oceanology 2012, 52, 206-218. [CrossRef]

43. Fenaux, R. The Classification of Appendicularia (Tunicata): History and Current State. Mem. L'Institut Oceanogr. 1993, 17, 1-123.

44. O'Sullivan, D. A Guide to the Pelagic Tunicates of the Southern Ocean and Adjacent Waters; ANARE Research Notes 8; Antarctic Division: Kingston, Australia, 1983.

45. Capitanio, F.L.; Curelovich, J.; Tresguerres, M.; Negri, R.M.; Viñas, M.D.; Esnal, G.B. Seasonal cycle of Appendicularians at a coastal station $\left(38^{\circ} 28^{\prime}\right.$ S, $57^{\circ} 41^{\prime}$ W) of the SW Atlantic Ocean. Bull. Mar. Sci. 2008, 82, 171-184.

46. Sato, R.; Tanaka, Y.; Ishimaru, T. Species-specific house productivity of appendicularians. Mar. Ecol. Prog. Ser. 2003, 259, 163-172. [CrossRef]

47. Uye, S. Length-weight relationship of important zooplankton from the Inland Sea of Japan. J. Oceanogr. 1982, 38, 149-158. [CrossRef]

48. Deibel, D. Feeding mechanism and house of the appendicularian. Oikopleura Vanhoeffeni. Mar. Biol. 1986, 93, 429-436. [CrossRef]

49. Fenaux, R. Anatomy and functional morphology of the Appendicularia. In The Biology of Pelagic Tunicates; Bone, Q., Ed.; Oxford University Press: New York, NY, USA, 1998; pp. 25-34.

50. Venables, W.N.; Smith, D.M.; R Core Team. An Introduction to R, Notes on R: A Programming Environment for Data Analysis and GraphicsVersion 4.1.0. Available online: https:/ / cran.r-project.org/doc/manuals/r-release/R-intro.pdf (accessed on 27 May 2021).

51. Oksanen, J.; Kindt, R.; Legendre, P.; O’Hara, B.; Henry, M.; Stevens, H. The vegan package. Community Ecol. Package 2013, 10, 631-637.

52. Jażdżewski, K.; Kittel, W.; Łotocki, K. Zooplankton studies in the southern Drake Passage and in the Bransfield Strait during the austral summer (BIOMAS-FIBEX, February-March 1981). Pol. Polar Res. 1982, 3, 203-242.

53. Witek, Z.; Kittel, W.; Czykieta, H.; Żmijewska, M.I.; Presler, E. Macrozooplankton in the southern Drake Passage and in Bransfield Strait during BIOMASS-SIBEX (December 1983-January 1984). Pol. Polar Res. 1985, 6, 95-115.

54. Tokioka, T. Taxonomic studies of Appendicularians collected by the Japanese Antarctic Research Expedition, 1957. Sci. Rep. Jap. Antarct. Res. Exped. 1964, 21,1-16.

55. Lindsay, M.; Williams, G. Distribution and abundance of Larvaceans in the Southern Ocean between 30 and $80^{\circ}$ E. Deep Sea Res. II 2010, 57, 905-915. [CrossRef]

56. Troedsson, C.; Bouquet, J.-M.; Aksnes, D.L.; Thompson, E.M. Resource allocation between somatic growth and reproductive output in the pelagic chordate Oikopleura dioica allows opportunistic response to nutritional variation. Mar. Ecol. Prog. Ser. 2002, 243, 83-91. [CrossRef]

57. Gorsky, G.; Palazzoli, I.; Fenaux, R. Influence of temperature changes on oxygen uptake and ammonia and phosphate excretion. In relation to body size and weight, in Oikopleura dioica (Appendicularia). Mar. Biol. 1987, 94, 191-201. [CrossRef]

58. Pakhomov, E.A.; McQuaid, C.D. Distribution of surface zooplankton and seabirds across the Southern Ocean. Polar Biol. 1996, 16, 271-289. [CrossRef]

59. Pakhomov, E.A.; Perissinotto, R.; McQuaid, C.D.; Froneman, P.W. Zooplankton structure and grazing in the Atlantic sector of the Southern Ocean in late summer 1993. Part 1. Ecological zonation. Deep Sea Res. I 2000, 47, 1663-1686. [CrossRef] 
60. Hosie, G.W.; Fukuchi, M.; Kawaguchi, S. Development of the Southern Ocean Continuous Plankton Recorder survey. Prog. Oceanogr. 2003, 58, 263-283. [CrossRef]

61. Takahashi, K.T.; Kawaguchi, S.; Hosie, G.W.; Toda, T.; Naganobu, M.; Fukuchi, M. Surface zooplankton distribution in the Drake Passage recorded by Continuous Plankton Recorder (CPR) in late austral summer of 2000. Polar Sci. 2010, 3, 235-245. [CrossRef]

62. López Urrutia, A.; Harris, R.P.; Smith, T. Predation by calanoid copepods on the appendicularian Oikopleura dioica. Limnol. Oceanogr. 2004, 49, 303-307. [CrossRef]

63. Swart, N.C.; Gille, S.T.; Fyfe, J.C.; Gillett, N.P. Recent Southern Ocean warming and freshening driven by greenhouse gas emissions and ozone depletion. Nat. Geosci. 2018, 11, 836-841. [CrossRef]

64. Trull, T.W.; Passmore, A.; Davies, D.M.; Smith, T.; Berry, K.; Tilbrook, B. Distribution of planktonic biogenic carbonate organisms in the Southern Ocean south of Australia: A baseline for ocean acidification impact assessment. Biogeosciences 2018, 15, 31-49. [CrossRef]

65. Mańko, M.K.; Panasiuk-Chodnicka, A.A.; Żmijewska, M.I. Pelagic coelenterates in the Atlantic sector of the Arctic Ocean: Species diversity and distribution as water mass indicators. Oceanol. Hydrobiol. Stud. 2015, 44, 466-479. [CrossRef]

66. Słomska, A.W.; Panasiuk-Chodnicka, A.A.; Żmijewska, M.I.; Mańko, M.K. Variability of Salpa thompsoni population structure in the Drake Passage in summer season 2010. Pol. Polar Res. 2015, 36, 391-404. [CrossRef]

67. Groeneveld, J.; Berger, U.; Henschke, N.; Pakhomov, E.A.; Reiss, C.S.; Meyer, B. Blooms of a key grazer in the Southern Ocean -An individual-based model of Salpa Thompsoni. Prog. Oceanogr. 2020, 185, 102339. [CrossRef]

68. Plum, C.; Hillebrand, H.; Moorthi, S. Krill vs salps: Dominance shift from krill to salps is associated with higher dissolved N:P ratios. Sci. Rep. 2020, 10, 5911. [CrossRef]

69. Panasiuk, A.; Grzonka, L.; Prątnicka, P.; Wawrzynek-Borejko, J.; Szymelfenig, M. Zonal variability of pelagic Siphonophora (Cnidaria) in the atlantic sector of the southern ocean. J. Sea. Res. 2020, 165, 101951. [CrossRef] 